\title{
Theory of the Transient Current Response for the Homogeneous Mediated Enzyme Catalytic Mechanism at the Rotating Disc Electrode
}

\author{
B Manimegalai ${ }^{1}$, L Rajendran $^{1}$, MEG Lyons ${ }^{2, *}$ \\ ${ }^{1}$ Department of Mathematics, AMET Deemed to be University, Kanathur, Chennai-603112. \\ ${ }^{2}$ School of Chemistry \& AMBER National Centre, University of Dublin, Trinity College Dublin, \\ Dublin 2, Ireland. \\ *E-mail: melyons@tcd.ie (MEG Lyons)
}

Received: 9 May 2021 / Accepted: 17 June 2021 / Published: 10 August 2021

This paper presents the approximate analytical expression for transient and steady-state concentration profiles of enzymes, mediator, substrate and current. The transport and kinetics of the reaction in the diffusion layer with a rotating disc electrode are described using closed-form solutions of homogeneous systems. These new approximate analytical expressions are valid for all values of parameters. Furthermore, in this work, the numerical simulation is also presented using the Matlab program. The analytical results are compared with simulation results, and satisfactory agreement is noted.

Keywords: Nonlinear reaction kinetics; Rotating-disc electrode; Transient conditions; Amperometric response of Homogeneous mediated enzyme catalysis.

\section{FULL TEXT}

(C) 2021 The Authors. Published by ESG (www.electrochemsci.org). This article is an open access article distributed under the terms and conditions of the Creative Commons Attribution license (http://creativecommons.org/licenses/by/4.0/). 